\title{
KARYA HERMIN INSTIARININGSIH (MBAH NING) DALAM KERANGKA KRITIK HOLISTIK
}

\author{
Siti Nurhikmah \\ Program Studi Seni Rupa Murni-FSRD \\ Universitas Sebelas Maret, Surakarta \\ khury28@gmail.com
}

\begin{abstract}
ABSTRAK
Artikel ini memiliki tujuan menjawab permasalahan tentang, karakeristik, latar belakang terciptanya Wayang Beber sebagai konsep, dan proses kreatif lukisan Wayang Beber karya Hermin Istiariningsih. Data dan sumber data dihimpun dari informan, tempat, peristiwa melalui survey langsung, dan juga data pustaka. Permasalahan berdasarkan pada salah satu seni tradisi yaitu lukisan Wayang Beber yang semakinlangka dan sedikit yang melestarikan. Salah satu seniman Hermin Istiariningsih yang hidup sederhana tidak menyurutkan semangat dalam menekuni seni lukis Wayang Beber. Metode yang digunakan dalam penelitian ini adalah metode kualitatif, yaitu, dengan wawancara terstruktur, observasi, mengkaji dokumen dan arsip. Ciri khas karya Mbah Ning adalah lukisan Wayang Beber bukan teknik Sungging dengan menggunakan campuran warna cat lukis, warna dari daun dan kulit kayu secara konsisten, beliau juga merupakan elukis Wayang Beber perempuan satu-satunya yang ada di Indonesia.
\end{abstract}

Kata kunci : wayang beber; kreatif; karakteristik; tradisi; kritik holistik

\begin{abstract}
The article aims at answering problems about the characteristics of painting, the background of Wayang Beber as a concept, and the creative process of Wayang Beber painting by Hermin Istiariningsih. Data and source of data were collected from informants, place, and event through direct observation and library data. Research problems were based on one of traditional arts namely Wayang Beber painting that's getting more rare and just a few of people who're willing to conserve it. One of artists who is willing to conserve it is Hermin Istiariningsih. Despite of having a modest life, she's still very enthusiastic in pursuing the portraiture of Wayang Beber. Method used in this research was qualitative method consisting of doing structured interview, doing observation and studying documents and archives. The unique characteristic of Mbah Ning's work is the painting of Wayang Beber without Sungging tehnic made by using the mixture of color from paints, leaves and barks consistently. She is also the one and only female painter of Wayang Beber in Indonesia.
\end{abstract}

Keywords: Wayang Beber; creative; characteristic; tradition; holistic criticism 


\section{Siti Nurhikmah}

\section{PENDAHULUAN}

Wayang Beber adalah warisan leluhur yang perlu dilestarikan keberadaannya. Keberadaan Wayang Beber sangat memprihatinkan bahkan termasuk wayang langka artinya sudah jarang dipentaskan di tengah-tengah masyarakat (Soetarno, 2010:182). Wayang Beber adalah jenis pertunjukkan dengan gambargambar sebagai objek pertunjukkan. Gambar-gambar dilukiskan pada selembar kertas atau kain. Gambar dibuat dari satu adegan ke adegan lain secara berurutan. Usia Wayang Beber yang lebih tua dari wayang kulit dan wayang-wayang lain, tidak menjamin ketenarannya dikalangan para pelukis muda. Jarang dari kalangan seniman muda yang mempelajari lukisan Wayang Beber. Jenis wayang ini oleh sebagian orang dianggap paling tua, tetapi sebagian mengatakan wayang kulitlah paling awal diciptakan oleh orang di Pulau Jawa (Nanda, 2010:14-15).

Awal mulanya Wayang Beber hanya terdapat di Wonosari dan Pacitan. Seiring perkembangannya Wayang Beber juga berkembang di Surakarta. Eksistensi Wayang Beber di Surakarta saat ini mulai surut. Masyarakat banyak yang tidak mengerti bahkan tidak peduli dengan Wayang Beber. Meskipun demikian di Surakarta Wayang Beber pernah ditampilkan di Taman Budaya Jawa Tengah untuk memenuhi kebutuhan kerinduan masyarakat pada wayang (Wardani, 2013:90).

Teknologi dan perkembangan zaman yang semakin pesat, ketertarikan pada seni tradisi semakin berkurang. Wayang Beber yang awalnya sebagai media tutur dalang, kemudian di kembangkan menjadi sebuah karya seni. Karya seni Wayang Beber tersebut berupa lukisan pada kaca dan kanvas. Lukisan kaca mempunyai tingkat kesulitan sendiri dalam proses melukisnya. Teknik yang digunakan juga berbeda dengan melukis pada sebidang kanvas.

Pelukis Wayang Beber yang masih aktif berkarya yaitu Hermin Istiariningsih atau yang biasa di panggil Mbah Ning. Beliau tinggal di daerah Wonosaren, Jagalan, Jebres. Mbah Ning adalah salah satu pelukis Wayang Beber yang ada di Surakarta. Mbah Ning berhasil menuangkan ide melukis Wayang Beber di atas kaca ataupun kain berkat kegigihannya dalam menekuni seni lukis Wayang Beber.

Mbah Ning merupakan sosok perupa yang tangguh karena diusianya yang terbilang tidak muda lagi, beliau masih eksis dalam berkarya khususnya melukis Wayang Beber. Walaupun beliau hidup sederhana tetapi kemauan untuk melestarikan budaya Nusantara seperti Wayang Beber sangat tinggi.

Wayang Beber menjadi daya tarik untuk diteliti karena pada zaman modern 


\section{Siti Nurhikmah}

seperti sekarang banyak kebudayaan yang hampir terlupakan bagi masyarakat. Salah satu budaya bangsa yang harus tetap di jaga dan di lestarikan adalah Wayang Beber. Karya lukis yang dihasilkan dari Mbah Ning juga berbeda dengan mengambil objek Wayang Beber yang di lukis pada media kaca dan kanvas. Selain keberlangsungan Wayang Beber semakin ditinggalkan, semangatnya dalam berkarya juga tingginya kesadaran sebagai bangsa yang mencintai kesenian tradisi khususnya seni lukis Wayang Beber. Berdasarkan latar belakang maka yang dibahas mengenai karakteristik, Wayang Beber sebagai konsep karya dan proses kreatif dari lukisan Wayang Beber Karya Mbah Ning.

Lukisan Wayang Beber Mbah Ning mempunyai karakter tersendiri dan konsep sebagai latar belakang penciptaan, untuk itu teori yang digunakan dalam penelitian ini adalah melalui kritik holistik. Kritik holistik memaparkan tiga kelompok pendekatan kritik, yakni dengan komponen seniman dan latar belakang budayanya, karya seni sebagai faktor objek dan penghayat karya seni. Latar belakang yang berupa segala hal yang berkaitan dengan yang terjadi sebelum karya, konteks awalnya, sebelum program terwujud dan juga proses. Kondisi formal yang secara objektif berupa segala yang terjadi bisa ditangkap dengan indera pada karya. Dampak atau tanggapan yang beragam sebagai dari faktor afektif (Sutopo, 2006:144).

Langkah penulisan dalam pembuatan laporan penelitian yaitu dengan cara mengumpulkan data melalui wawancara secara terstruktur (wawancara mendalam), dengan pihak terkait, observasi langsung, mengkaji dari dokumen dan arsip. Selanjutnya melakukan analisis data dengan cara mereduksi data untuk memberikan gambaran yang jelas terkait data yang dibutuhkan.

\section{PEMBAHASAN}

\section{Asal-usul Wayang Beber}

Wayang Beber merupakan lukisan Jawa masa lalu sebelum datangnya orang-orang Barat. Wayang Beber merupakan nenek moyang komik dan terdiri atas serangkaian gambar yang dilukis pada gulungan kertas dengan melukiskan secara berurutan mengikuti alur cerita (Wardani, 2013:91). Di Pulau Jawa terdapat dua jenis Wayang Beber yang pertama yaitu: Wayang Beber Gunung Kidul, Wonosari, Yogyakarta, dan yang kedua Wayang Beber di Karang Talun, Desa Bangunsari, Danaraja, Pacitan. Wayang Beber Wonosari menceritakan Sayembara Nguwot Penjalin Pinenthang (sayembara meniti rotan yang direntangkan), dengan lakon yang terkenal Remeng Mangunjaya, sedangkan Wayang Beber Pacitan dengan sengkalan Gawe Serabi Jinamah ing Wong (tahun $1614 \mathrm{Jw}$ atau $1692 \mathrm{M}$ ), dengan lakon 


\section{Siti Nurhikmah}

Jaka Kembang Kuning (Soetarno. dkk, 2010:184). Wayang Beber juga mengalami perkembangan dari masa ke masa. Berbagai cerita lakon Wayang Beber:

\section{a. Kerajaan Majapahit}

Wayang Beber Pacitan yang mengambil cerita Panji Asmara Bangun atau Jaka Kembang Kuning Putra Raja Jenggala. Berkembang sampai pada Masa Kerajaan Demak, tetapi para Wali menentang untuk pementasan Wayang Beber (Wayang menampilkan gambar-gambar manusia). Maka akhirnya Wayang Beber hanya bertahan sebagai pertunjukan rakyat pedesaan.

\section{b. Kerajaan Demak}

Pada Masa Kerajaan Demak terjadi peristiwa penting yaitu pergantian cerita Wayang Beber yang sebelumnya menampilkan cerita Purwa (MahabarataRamayana), diganti dengan cerita Gedog(Panji). Pada tahun 1486 Jawa atau 1564 Masehi oleh Sunan Bonang.

\section{c. Kerajaan Pajang}

Kisah tentang lahirnya Jaka Tingkir dan Wayang Beber, yaitu Ki Ageng Kebo Kelana akan mengadakan pesta untuk istrinya yang sedang hamil. Upacara dilakukan sebagai penembus janji. Anak yang dilahirkan diberi nama Joko Kaberet, diambil dari nama lain Wayang Beber yaitu karebet (klebet-klebet) (Wardani, 2013:91-92).

\section{Jenis-Jenis Wayang Beber}

a. Wayang Beber Pacitan

Wayang Beber Pacitan asli saat ini kondisinya rapuh karena sudah dipakai 14 keturunan (lihat gambar 1 halaman selanjutnya). Wayang Beber ini terbuat dari kertas gedog (kertas ponorogo). Tokoh pewayangan dilukis dengan menggunakan cat acrylic. Pentas Wayang Beber yang dilakukan dalang didukung beberapa pengrawit yang masing-masing memainkan kendang, kenong, gong dan juga rebab. Selain itu juga ada yang bertugas membakar kemenyan waktu pementasan Wayang Beber. Pembakaran kemenyan harus dilakukan karena sudah menjadi tradisi.

Menurut Afatara (dalam Sawega, 2013:105) pertunjukan Wayang Beber gaya Pacitan yang mengangkat roman percintaan antara Jaka Kembang Kuning dan Dewi Sekar Taji selama ini telah mengalami pergantian dalang hingga belasan dalang. Pada tahun 1988 artefak Wayang Beber tersimpan di Dusun Karang Talun, Desa Gendompol, Kecamatan Pringkuku, Kabupaten Pacitan Jawa Timur. 


\section{Siti Nurhikmah}

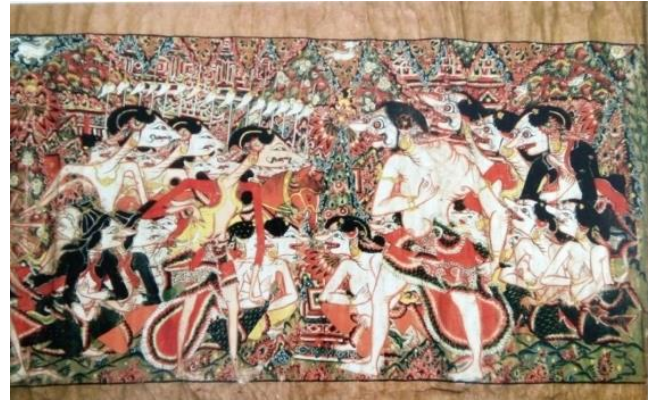

Gambar 1.

Wayang Beber Pacitan gulungan 2 adegan 4 (Sumber: Sawega, 2013:37)

b. Wayang Beber Wonosari

Wayang Beber Remeng

Mangunjaya, pusaka milik keluarga $\mathrm{Ki}$

Gunakarya, dari Dusun Gelaran, Desa

Bejiharjo, Kecamatan Karangmojo,

Kabupaten Gunung Kidul Provinsi Daerah

Istimewa Yogyakarta. Wayang Beber ini biasa disebut Wayang Beber Wonosari.

Perbedaan yang paling mendasar pada pada Wayang Beber Pacitan dan Wayang Beber Wonosari adalah terdapat pada dalangnya. Jika pada versi Wonosari posisi dalangnya berada di depan Wayang Beber, jika pada versi Pacitan posisi dalangnya berada di belakang Wayang Beber. Perbedaan yang berikutnya pada Wayang Beber Wonosari dengan Wayang Beber Pacitan, di antaranya Wayang Beber Wonosari sebagian besar bidang gambar tidak terisi penuh seperti pada Wayang Beber Pacitan, keliatannya lebih sederhana (lihat gambar 2 halaman selanjutnya). Bidang gambar yang kosong tidak dicat atau diwarna dengan warna kuning. Bahkan pada beberapa bagian terdapat elemen motif (gambar) yang hanya berupa outline tanpa diselesaikan dengan warna. Hal ini mengesankan bahwa Wayang Beber Remeng Mangunjaya tampak belum jadi. Cerita Wayang Beber Remeng Mangunjaya dibeberkan dalam lukisan kertas yang dibagi menjadi empat gulugan terdiri dari delapan belas adegan atau pejagong(Subandi,2011:37).

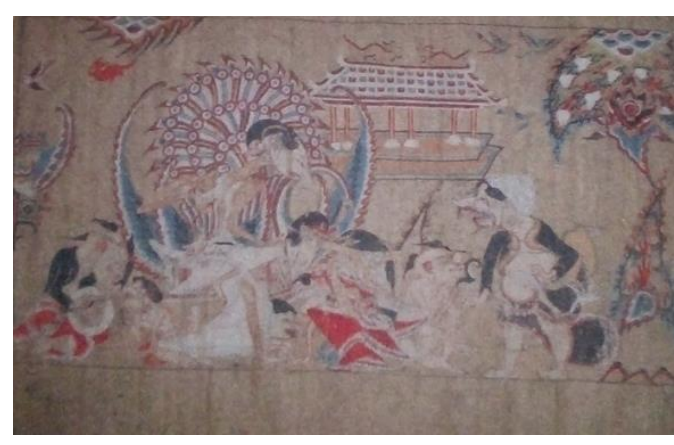

Gambar 2.

Wayang Beber Wonosari (Sumber: Sawega, 2013:71)

c. Wayang Beber Kontemporer Wayang Beber Kontemporer yang biasa disebut Wayang Beber Kota. Wayang Beber Kota yaitu Wayang Beber yang melukiskan kisah hidup manusia urban dengan segala problematikanya (lihat gambar 3 halaman selanjutnya). Sehingga dari kutipan Wayang Beber tersebut Wayang Beber Kontemporer muncul dan memiliki ciri khas berbeda dengan Wayang Beber tradisi. Setiap adegan yang di buat menggambarkan fenomena kekinian berupa kritik sosial, ekonomi dan lain-lain. 


\section{Siti Nurhikmah}

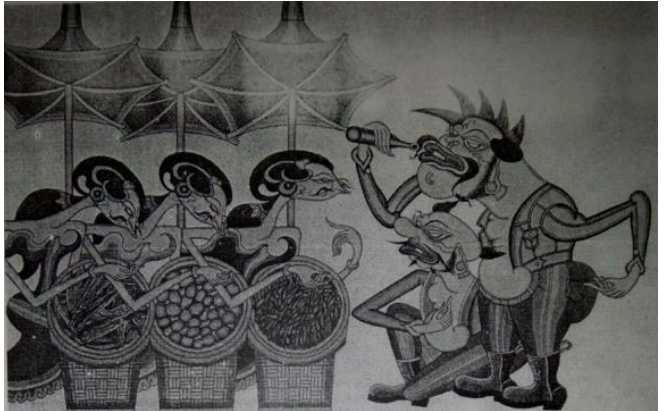

Gambar 3.

Wayang Beber Kota "Nagih Setoran" (Sumber: Sawega, 2013:87)

d. Wayang Beber Tani

Wayang Beber tani menceritakan tentang pedesaan yang pementasannya dari lingkup RT, dari desa ke desa mengajak anak-anak untuk pentas sekitar 10 menit berdongeng sekaligus bercerita. Faris Wibisono adalah seniman sekaligus dalang Wayang Beber Tani (lihat gambar 4 halaman di bawah ini) dengan menggunakan media daluwang (kertas tradisional jawa) (wawancara dengan Faris Wibisono, 20 Maret 2017).

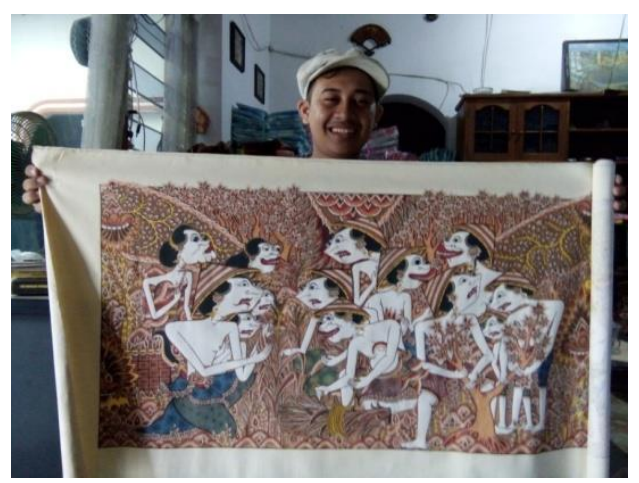

Gambar 4.

Faris Wibisono dan karya Wayang Beber Tani (Sumber dokumentasi : Siti Nurhikmah, 2017)

\section{Proses Kreatif}

Wujud seni mencangkup dua aspek, yakni nilai intrinsik dan nilai ekstrinsik seni, maka segi kreativitas harus ditinjau dari dua aspek tersebut. Aspek tersebut tanpa merusak kesatuan atau keutuhan karya seni. Hakikat karya seni adalah menentukan sesuatu yang baru atau hubungan baru dari suatu yang telah ada. Manusia menciptakan sesuatu bukan dari kekosongan. Setiap seniman menjadi kreatif dan besar karena bertolak dari bahan yang telah ada tercipta sebelumnya, inilah yang biasa disebut dengan tradisi. Seorang seniman melukis karena sebelumnya telah punya pengalaman melihat karya lukis.

Tradisi seni atau budaya seni telah ada jauh sebelum seniman dilahirkan. Setiap seniman belajar berkesenian dari tradisi masyarakatnya. Setiap karya yang merupakan kekayaan tradisi seni suatu masyarakat pada mulanya juga merupakan karya kreatif atau karya yang baru pada zamannya. Setiap seniman yang kreatif adalah seniman yang peka dan tanggap terhadap lingkungan hidupnya, baik tradisi budayanya maupun faktual lingkungannya. Kenyataan lingkungan manusia yang berubah-ubah akibat perubahan yang disebabkan oleh kerja budaya.

Orang yang mampu melahirkan sikap baru dan temuan baru untuk melenyapkan berbagai kejanggalan tersebut dapat disebut kreatif, meskipun caranya bersikap di pengaruhi atau bertolak dari sikap budaya yang telah tersedia dalam masyarakatnya. Kreativitas dapat ditunjukan kepada tradisi budaya maupun 


\section{Siti Nurhikmah}

kepada kenyataan faktual atau mungkin kedua-duanya (Sumandjo, 2000:84-85).

\section{Kritik Seni}

a. Pengertian Kritik Seni

Istilah seni rupa berasal dari bahasa Yunani krites berarti seorang hakim; krinein berarti menghakimi; criterion diartikan sebagai dasar penghakiman, dan kritikos berarti hakim kesenian. Fuad Hassan meninjau pengertian kritik dari istilah kritos atau krinein yang berarti memilah-milah atau memisah misah. Istilah kritik dalam bahasa Indonesia analog dengan istilah criticism dalam bahasa Inggris yang berarti kecaman atau kupasan. Apa yang disebut istilah kritik di dalam mencangkup istilah seni dlam rangka menganalisis, menginterprestasi, dan menilai karya seni (Mamannoor, 2001:39).

Menurut Jhon M. Hassan Shadily dalam Nooryan Bahari (2008:1) istilah "kritik seni" dalam bahasa Indonesia, sering juga disebut dengan istilah "ulas rupa", "kepuasan seni", "bahas seni” atau "bincang seni". Hal ini disebabkan istilah "kritik" bagi sebagian orang yang sering beranggapan negatif yang berarti kecaman, celaan, gugatan, hujatan, dan lain-lain.

\section{b. Kritik Seni Holistik}

Praktek kritik, bila nilai karya didasarkan pada praktek emosi penghayatan dengan mengabaikan faktor-faktor lainnya, maka kedudukan seniman bisa tergeser sama sekali dari proses pembentukan nilai dengan pesan yang mungkin disajikan lewat beragam bentuk karya artistik. Kelemahan utama pada kritik ini adalah subjeknya yang sangat menonjol bahkan peran seniman tidak mendapatkan peran yang memadai. Kecenderungan kritik ini hanya menekankan pada salah satu komponen, sehingga mengakibatkan kepincangan dalam penilaian karya Menurut Sutopo dalam (Kartika, 2007:108).

Menurut Sutopo dalam Mamannoor (2002:64) memaparkan tiga kelompok pendekatan kritik, yakni dengan komponen seniman dan latar belakang budayanya, karya seni sebagai faktor objek dan penghayat karya seni. Ketiga komponen tersebut sebagai sumber informasi saling tergantung dan membentuk susunan nilai karya dalam Kritik holistik.

Pandangan ini merupakan sintesis dari tiga dari kelompok aliran kritik, dengan penyajian suatu struktur kritik yang lengkap tanpa membedakan salah satu komponen seni yang ada. Karena kelompok ini tidak memandang salah satu faktor secara terpisah dari keseluruhannya yang mendukung karya, maka kritik sintesis ini disebut struktur kritik holistik. 


\section{Siti Nurhikmah}

\section{Penyebaran Lukisan Wayang}

\section{Beber di Surakarta}

Seni Wayang Beber sebenarnya belum mengalami kepunahan, akan tetapi perlu dilakukan tindakan atau langkahlangkah pelestarian lebih lanjut sehingga, Wayang Beber lebih eksis dan berkembang serta berkontribusi nyata pada dunia kesenirupaan. Kontribusi ini nantinya juga berdampak pada peningkatan ekonomi para pelakunya yang lebih luas untuk Seni Wayang Beber.

Lukis Wayang Beber sudah dikenal di Keraton Kasunan Surakarta, sejak tahun 1930an ketika M.Ng. Atmosupomo seorang abdi dalem atau pelukis keraton yang semula banyak mencipta karya lukis tentang Wayang dari cerita Ramayana dan Mahabarata, ditugaskan untuk mereplika lukis Wayang Beber Pacitan. Pak Bei, Atmosupomo akrab dipanggil adalah ahli dalam lukisan pawukon (perhitungan atau peramalan hari dalam pandanan Jawa). Atmosupomo lantas membuat beberapa replika lukis Wayang Beber dari semua adegan yang ada dan kemudian menjadi ciri atau gaya baru dalam Wayang Beber. Ciri karyanya adalah isian ornamen yang dikenal luwes juga pewarnaannya yang mempunyai kesan kuat namun rapi.

Surakarta mempunyai pelukis Wayang Beber perempuan yaitu Hermin Istiaringsih (Mbah Ning), yang akan dibahas mulai dari; a. Latar Belakang kehidupan dan Karakteristik lukisan Wayang Beber (Mbah Ning)

Hermin Istiariningsih (Mbah Ning) seorang pelukis spesialis Wayang Beber. Di masa kecilnya Mbah Ning suka menyimak dongeng cerita Panji dari kakeknya. Dongeng sang kakek membekas di memori Mbah Ning sampai beliau hafal betul kisah yang ada di cerita Panji.

Lulus SMA, Mbah Ning merantau ke Solo dan berjumpa dengan Sutrisno, yang kemudian menjadi suami dari Mbah Ning. Sebelum memutuskan untuk melukis Wayang Beber Mbah ning mengisi waktu luangnya dengan membordir, pada akhirnya di tahun 1984 beliau memutuskan untuk berhenti membordir. Mbah Ning tidak mengira bahwa dongeng Panji yang selama ini adalah kisah Wayang yang berasal dari Jawa. Dari sinilah beliau mendalami cerita Panji dan lukisan Wayang Beber. Didasari semangat dan rasa ingin tahu yang besar beliau mulai membuat lukisan Wayang Beber cerita Panji.

Melukis Wayang Beber merupakan sebuah panggilan hidup dan dibantu suaminya, mulai melukis dari cerita Joko Kembang Kuning. Mbah Ning juga dibantu oleh M Suharto, dosen Seni Rupa di Universitas Sebelas Maret Surakarta, beliau mendapat fasilitas untuk memahami teks dan teknis melukis. Mbah Ning tidak begitu 


\section{Siti Nurhikmah}

saja puas dengan hasil lukisannya, beliau terus memperbaiki teknik melukis Wayang Beber. Walaupun karyanya sedikit yang terjual, tetapi Mbah Ning tidak menyerah begitu saja, beliau diberi semangat dan dorongan oleh suaminya agar tetap melukis Wayang Beber.

Gaya dari lukisan Mbah Ning bercorak tradisional, bentuk wayang yang merupakan deformasi dari bentuk orang tidak mengalami deformasi ulang, dan juga penggunaan dalam pewarnaan. Ukuran kanvas yang digunakan biasanya sekitar satu meter hingga empat meter pada sebidang kanvas, sedangkan pada kaca ukurannya satu setengah meter. Lukisan Wayang Beber Mbah Ning hampir tidak ada ruang kosong semuanya terisi penuh (lihat gambar 5 halaman selanjutnya). Mbah Ning menggunakan motif hiasan, bentuk flora dan fauna dengan warana merah, keemasan, biru, coklat yang merupakan warna tradisional menjadi ciri khas lukisannya.



Gambar 5.

Karya lukis Wayang Beber Hermin Istiariningsih (Sumber dokumentasi: Siti Nurhikmah,2017)
Melukis Wayang Beber di tekuni Mbah Ning bertahun-tahun, barulah beliau mendapatkan tawaran untuk pameran di lembaga dalam negeri. Setelah itu barulah karya Mbah Ning dipamerkan di berbagai Negara seperti Eropa dan Suriname.

Tahun $2004 \quad$ Mbah Ning mengadakan pameran tunggal lukisan Wayang Beber di Surakarta. Dalam pamerannya beliau meminta bantuan Tri Ganjar Wicaksono untuk mendalang Wayang Beber Karyanya, yang kemudian sekarang dikenal sebagai dalang Wayang Beber Kontemporer. Tahun 2006 Mbah Ning mengadakan pameran kembali atas permintaan dari galeri di Ubud, Bali. Selain itu beliau juga diminta melukis Wayang Beber untuk di koleksi, disinilah beliau melukis Wayang Beber paling panjang dengan ukuran empat meter.

Seniman yang karyanya sudah sampai Internasional tidak menjamin kehidupan Mbah Ning. Beliau dan suaminya masih tinggal di rumah petak yang sempit ditambah dengan rumahnya yang dijadikan tempat penyimpanan karya Walapun karya seni itu adalah benda yang bernilai tinggi dengan harga yang relatif mahal tetapi tidak jarang karyanya dihargai sangat murah oleh pembeli. "pernah juga lukisan Wayang Beber beliau dibawa oleh pejabat, lewat perantara dan lupa tidak dibayar". Padahal untuk mengerjakan karya 


\section{Siti Nurhikmah}

lukisan Wayang Beber beliau harus mengerjakannya berhari-hari.
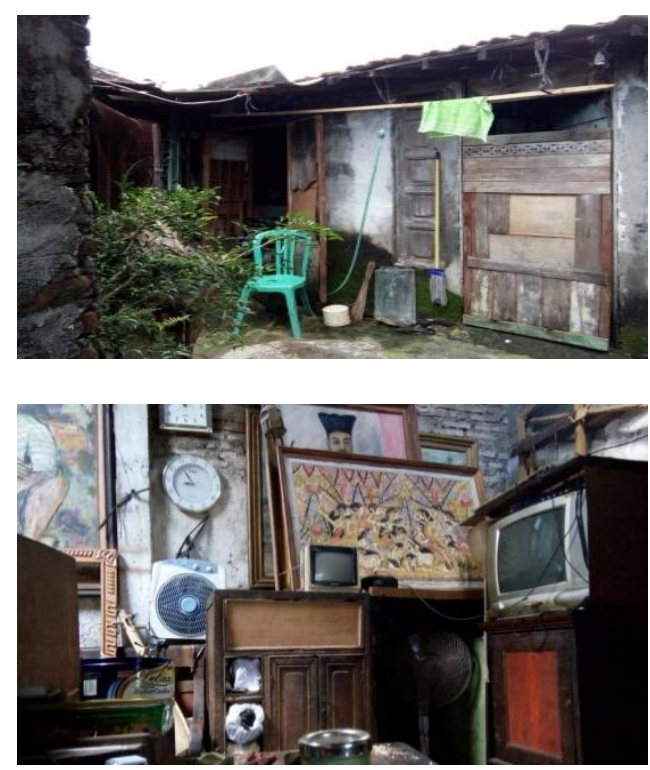

Gambar 6.

Kondisi rumah Hermin Istiariningsih (Mbah Ning) (Sumber dokumentasi: Siti Nurhikmah,2017)

Semangat Mbah Ning di usianya yang relatif tidak muda, perlu dicontoh oleh seniman muda penerus lukisan Wayang Beber khususnya di daerah Surakarta. Beliau tidak pernah mengeluh, bagi beliau yang terpenting adalah terus berkarya selagi mampu menghasilkan karya seni. Banyak dari kalangan pelajar untuk belajar melukis Wayang Beber di rumahnya tetapi tidak pernah sampai tuntas, banyak dari mereka yang tidak sabar karena melukis Wayang Beber perlu tingkat ketelitian yang tinggi (wawancara dengan Mbah ning 17 oktober 2016).

\section{b. Wayang Beber Sebagai Konsep Lukisan Mbah Ning}

Konsep yang dipilih dalam melukis Wayang Beber adalah mengambil cerita

Panji. Pewarnaannya menggunakan warna tradisional dengan hiasan penuh diseluruh karya tanpa menyisahkan ruang kosong. Dengan spesialis melukis Wayang Beber Mbah Ning juga ikut melestarikan warisan budaya Indonesia yang dari segi peminat mulai berkurang dan cenderung ditinggakan. Keberadaan Wayang Beber yang semakin memprihatinkan dari waktu ke waktu menjadikan Mbah Ning tetap bertahan dengan melukis Wayang Beber.

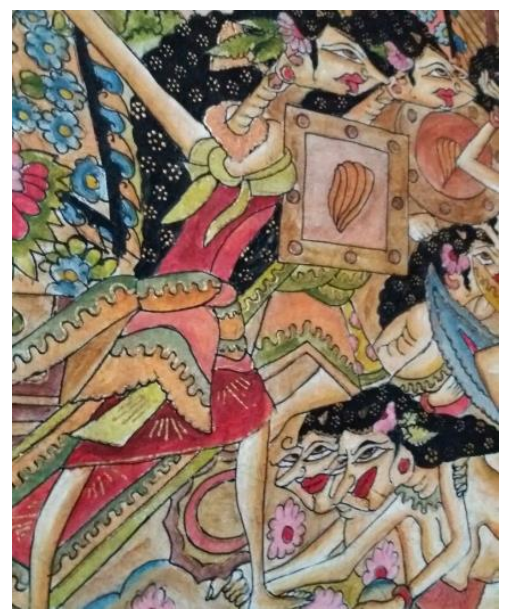

Gambar 7.

Wayang Beber (Mbah Ning) dengan menggunakan warna tradisional

(Sumber dokumentasi : Siti Nurhikmah, 2017)

c. Proses Kreatif Lukisan Wayang Beber Mbah Ning

Mbah Ning mulai melukis Wayang Beber dengan menggambarkan sketsa terlebih dahulu. Beliau menggunakan warna tradisi dan juga menggunakan cat-cat modern untuk melukis seperti rembard, acrylic, cat minyak, tinta bak (tinta cina). Mbah Ning juga memadukan pewarnaan dengan memakai warna dari daun dan kulit 


\section{Siti Nurhikmah}

kayu. Pemakaian cat lukis sintetis dilakukan karena gampang dan mudah untuk didapatkan. Mbah Ning menggunakan media malukis di atas kanvas dan juga kain yang halus. Tidak jarang orang yang memesan lukisan Wayang Beber Mbah Ning. Jika ada pesanan beliau hanya menuruti permintaan.

\section{Teknik karya Wayang Beber Mbah} Ning dalah teknik lukis yang bukan menggunakan teknik sugging pada umumnya. Pengembangan teknik pada lukisan Wayang Beber yang dimiliki Mbah Ning sendiri sebagai ciri khas dari karyanya, sehingga orang mudah mengenali karya beliau karena selalu menggunakan warna-warna yang konsisten dengan warna tradisi.
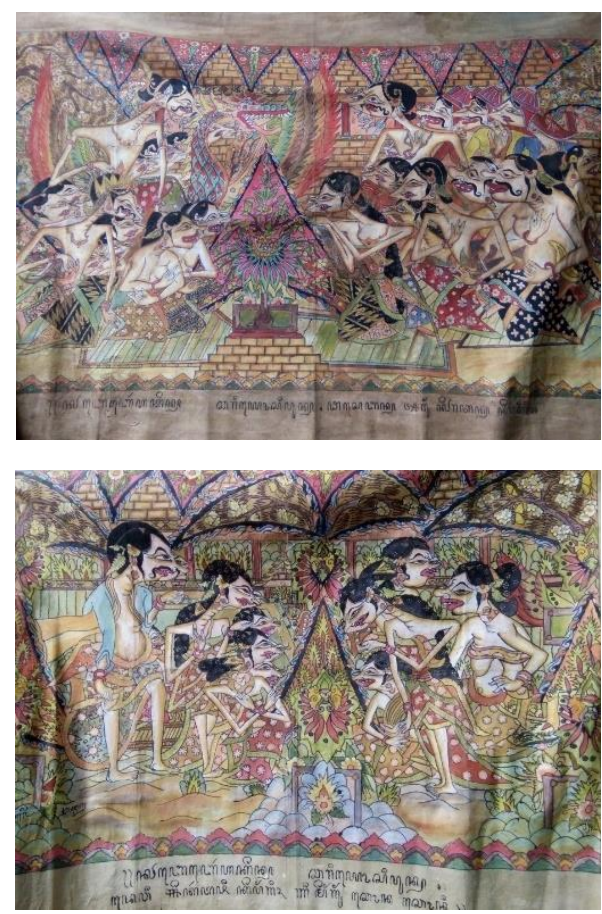

Gambar 8.

Karya-karya Lukis Wayang Beber Mbah Ning (Sumber Dokumentasi: Siti Nurhikmah, 2017)

Wayang Beber karya Mbah Ning berbeda dengan seniman lain karena teknik yang digunakan menggunakan teknik lukis bukan teknik sungging. Penikmat seni melihat karya Mbah Ning akan mudah mengenalinya pada pemakaian warna yang konsisten jika dilihat.

\section{PENUTUP}

Wayang Beber merupakan salah satu kebudayaan Indonesia yang keberadaannya semakin langka dan jarang dipentaskan di tengah-tengah masyarakat. Banyak masyarakat yang tidak tahu dengan Wayang Beber karena kalah populer dari Wayang kulit. Tetapi di sisi lain Mbah Ning memperjuangkan lukisan Wayang Bebernya, beliau merupakan satu-satunya pelukis perempuan Wayang Beber.

Kehidupan Mbah Ning memang terbilang sederhana tetapi di usianya yang tidak muda lagi, semangat dan perjuangannya perlu dicontoh oleh perupaperupa generasi muda sebagai penererus budaya bangsa. Kondisinya yang saat ini sering sakit-sakitan tidak membuat Mbah Ning berhenti melukis Wayang Beber. Ketekunannya dan keuletan belajar melukis Wayang Beber membuahkan hasil. Karyanya tidak hanya didalam negeri tetapi sudah sampai ke mancanegara.

Ciri khas lukisan Mbah Ning dari secara visual memang terbilang sederhana tetapi mempunyai karakter tersendiri, jika melihat lukisan Wayang Beber Mbah Ning 


\section{Siti Nurhikmah}

mudah dikenali mulai dari warna-warna yang digunakan sampai bentuk Wayang yang dilukis dengan mengambil cerita Panji. Lukisan Mbah Ning mudah dikenali oleh masyarakat dengan goresannya yang langsung dan mengembalikan bentuk wayangnya ke dalam lukisan wayang tiga dimensi. Penggunaan warna Mbah Ning juga konsisten dengan warna dari cat lukis, tinta bak (tinta cina), tidak jarang mencampurkan warna dari daun dan kulit kayu. Mbah Ning satu satunya pelukis Wayang Beber perempuan yang ada di Indonesia.

\section{KEPUSTAKAAN}

Bahari, Nooryan. 2008. Kritik Seni. Yogyakarta: Pustaka Pelajar.

Kartika, Dharsono Sony. 2007. Kritik Seni. Bandung: Rekayasa Sains.

Mamanoor. 2002. Wacana Kritik Seni Rupa di Indonesia. Bandung: Yayasan Adikarya IKAPI dan The Ford Fundation.

Nanda M. H. 2010. Wayang. Yogyakarta: Bintang Cemerlang.

Sawega, Ardus M. 2013. Wayang Beber Antara Inspirasi dan Transformasi.

Surakarta: Perpustakaan Nasional.

Soetarno, dkk.2010. Wayang Kulit dan Perkembangannya. Surakarta: ISI Press Solo.

Subandi, dkk.2011. Wayang Beber Remeng Mangunjaya Gelaran Wonosari Dan Wayang Beber Jaka Kembang KuningKarang talun Pacitan Serta
Persebarannya Di Seputar Surakarta. Surakarta: ISI Press Solo.

Sumardjo, Jakob. 2000. Filsafat Seni. Bandung: ITB.

Wardani, Nugraheni Eko, dkk. 2013. JenisHal| 124 Jenis Teater Wayang di Surakarta. surakarta: UPT UNS Press.

Sumber lain:

1. Wawancara dengan narasumber Hermin Istiariningsih (Mbah Ning), Wonosaren Rt. 04/08 No 44, Jagalan, Jebres, Solo.

2. Wawancara dengan narasumber suami Mbah Ning (Sutrisno), Wonosaren Rt. 04/08 No 44, Jagalan, Jebres, Solo.

3. Wawancara dengan narasumber Faris Wibisono (Seniman Wayang Beber sekaligus dalang Wayang Beber), Jl. Kalimasada 2 No. 11, Kauman, Surakarta. 